\title{
Contribution to the development of a food guide in Benin: linear programming for the optimization of local diets
}

\author{
Sarah Levesque ${ }^{1}$, Hélène Delisle ${ }^{1, *}$ and Victoire Agueh ${ }^{2}$ \\ 'WHO Collaborating Centre on Nutrition Changes and Development, Department of Nutrition, Faculty of Medicine, \\ Lilian-Stewart Building, University of Montreal, PO Box 6128 Downtown Station, Montreal, Quebec, Canada, H3C \\ 3J7: ${ }^{2}$ Institut Régional de Santé Publique (Regional Public Health Institute), Ouidah, Bénin
}

Submitted 22 August 2013: Final revision received 27 March 2014: Accepted 28 March 2014: First published online 24 April 2014

\begin{abstract}
Objective: Food guides are important tools for nutrition education. While developing a food guide in Benin, the objective was to determine the daily number of servings per food group and the portion sizes of common foods to be recommended.

Design: Linear programming (LP) was used to determine, for each predefined food group, the optimal number and size of servings of commonly consumed foods. Two types of constraints were introduced into the LP models: (i) WHO/FAO Recommended Nutrient Intakes and dietary guidelines for the prevention of chronic diseases; and (ii) dietary patterns based on local food consumption data recently collected in southern Benin in 541 adults. Dietary intakes of the upper tertile of participants for diet quality based on prevention and micronutrient adequacy scores were used in the LP algorithms.

Setting: Southern area of the Republic of Benin.

Subjects: Local key-players in nutrition ( $n$ 30) from the government, academic institutions, international organizations and civil society were partners in the development of the food guide directed at the population.

Results: The number of servings per food group and the portion size for eight age-sex groups were determined. For four limiting micronutrients $(\mathrm{Fe}, \mathrm{Ca}$, folate and $\mathrm{Zn}$ ), local diets could be optimized to meet only $70 \%$ of the Recommended Nutrient Intakes, not $100 \%$.

Conclusions: It was possible to determine the daily number of servings and the portion sizes of common foods that can be recommended in Benin with the help of LP to optimize local diets, although Recommended Nutrient Intakes were not fully met for a few critical micronutrients.
\end{abstract}

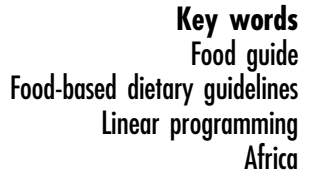

Chronic non-communicable diseases are the leading cause of mortality worldwide ${ }^{(1)}$. Chronic diseases related to nutrition are no longer the problem of developed countries only. The socio-economic costs of chronic disease management are huge and therefore prevention is essential, and it is feasible ${ }^{(2-4)}$. In low-income countries, nutrition-related chronic diseases are on the rise, but undernutrition persists: this is the double burden of malnutrition ${ }^{(5)}$. Addressing the double burden of malnutrition is compelling and requires mutisectorial strategies targeting the food supply, health care and education. Local health and nutrition professionals have to be trained adequately in order to prevent and manage not only malnutrition due to deficiencies, but also what is called 'overnutrition', i.e. obesity and other nutrition-related diseases such as diabetes and CVD ${ }^{(6)}$. Additionally, culturally sensitive and population-specific educational tools are required.

Following the International Nutrition Conference of 1992, the FAO and WHO recommended that countries develop food-based dietary guidelines (FBDG) in order to promote healthy eating in their population ${ }^{(7)}$. By 2005, seventy-five countries had FBDG, including thirty-three in Europe and a few in developing countries of Latin America, Asia and Africa ${ }^{(8,9)}$.

Key concepts in developing dietary guidelines are that they address dietary patterns and that they be practical, comprehensible and culturally acceptable. FBDG should be based on locally consumed foods. They should address existing nutrient deficiencies and excesses, and the resulting nutrition-related public health problems of a specific country or community ${ }^{(10)}$. FBDG usually include simple messages, like recommending a varied diet or the consumption of fruits and vegetables every day, and avoidance of excessive salt or sugar or alcohol consumption. They may also integrate food guides that provide more specific advice on the number and size of servings of foods belonging to different groups, for adults and for other physiological groups of consumers. Additionally, food guides frequently propose pictorial representations of food groups and individual 
food servings ${ }^{(11,12)}$. FBDG and food guides are based on current scientific evidence on nutritional requirements and diet-related diseases on the one hand, and on local dietary patterns and culinary practices on the other. They provide information for food choice, meal preparation and meal planning. Available data on their effectiveness suggest that they enhance awareness and understanding of what healthy eating is about ${ }^{(13)}$. Dietary guidelines permit the development of healthy eating scores or indices on the basis of adherence to the recommendations. Using this method, a few studies in developed countries have reported that dietary guidelines improved eating practices ${ }^{(14,15)}$. FBDG also serve as a basis for nutrition policy, as reported in Japan $^{(14)}$. Despite limitations, FBDG are seen as valuable tools to foster healthy eating according to a review on implementation of FBDG in Chile, Germany, New Zealand and South Africa ${ }^{(16)}$

The development of FBDG is a stepwise process that should involve local stakeholders ${ }^{(10,17)}$. This is the approach being used in the Republic of Benin (West Africa) for the development of a local food guide. This type of dietary guidance was deemed essential to halt the progression of chronic diseases while ensuring adequate intake to prevent deficiencies. Obesity and other cardiometabolic risk factors are indeed rising rapidly in the country and particularly in Cotonou ${ }^{(18)}$. Eating habits, along with physical activity, play a significant part in the development of these health conditions and for their prevention ${ }^{(19)}$. This is the rationale for initiating in 2009 the process of FBDG development in Benin.

The FBDG development process began with locally formulating and validating ten dietary recommendations based on WHO guidelines for the prevention of chronic diseases ${ }^{(20)}$. The next step consisted of defining the food groups and the pictorial presentation of the food guide. Five food groups were agreed upon: cereals/tubers; plant/ animal-protein foods; vegetables; fruits; and dairy products (or high-Ca foods as substitutes). The visual representation adopted is a round traditional house with a thatch roof, each food group being displayed as a wall layer. The present study encompassed the determination of the number of servings for each food group according to age and sex, and the serving size for most foods that are locally consumed according to recent data, using linear programming (LP).

\section{Experimental methods}

\section{Linear programming for the optimization of local diets}

The LP method used is based on the work of Ferguson et $a l^{(21)}$. LP is a rigorous mathematical approach that optimizes (minimizes or maximizes) a linear function of a set of decision variables while meeting linear constraints. In the area of nutrition, it can be used to formulate culturally specific, practical FBDG ensuring that the recommendations are as close as possible to the local eating patterns while simultaneously meeting the required nutrient intakes ${ }^{(21)}$. In our study, the objective function was to identify the optimal amounts of foods (in weight) per each food group that could meet nutrient requirements and comply with preventive diet guidelines while being consistent with local food habits.

All optimization models were performed on a standard Microsoft ${ }^{\circledR}$ Excel Solver 2.0, Simplex LP. The software used at the time would only accept a maximum of 200 constraints per model. Therefore, the fifty-two most frequently consumed foods, out of a total of 170 foods reported in the $24 \mathrm{~h}$ food recalls of dietary surveys, were used for optimization and subdivided in nine food categories (see Table 1). For each age and sex group, starting with adult men and women, two mathematical models were developed: one with only legumes, nuts and seeds as the protein source and one with only animal foods as the protein source. When the two food groups were combined the model selected only vegetable protein sources, whereas animal foods are an important source of haem- $\mathrm{Fe}^{(22)}$. Using alternative models ensured that optimal quantities of either protein-food group would be determined. The results of these two models were then merged and therefore if an animal protein source is not available, it can be substituted with a vegetable protein source. A total of eighteen LP models were constructed to include recommendations for all age and sex groups above the age of 2 years, as well as for pregnant and lactating women.

\section{Recommended energy and nutrient intakes as criteria in linear programming models}

Two sets of constraints or conditions were included in the LP algorithms: (i) recommended intakes and (ii) local eating habits. The nutritional constraints ensured that LP solutions would comply with the recommended dietary intakes for energy, macronutrients and twelve micronutrients. The Recommended Nutrient Intake (RNI) defined by the WHO/FAO for micronutrients was used as the minimum constraint ${ }^{(23-25)}$. Total energy expenditure was assessed with the WHO equations for BMR multiplied by a physical activity level factor of low to moderate $(1 \cdot 675)^{(26)}$. For children and adolescents, pre-calculated energy expenditure according to WHO was used ${ }^{(26)}$. For pregnant and lactating women, a supplement of $1255 \mathrm{~kJ}$ (300 kcal) and $1883 \mathrm{~kJ}$ ( $450 \mathrm{kcal}$ ), respectively, was added to the total energy needs for women ${ }^{(26)}$

For three micronutrients, i.e. Fe, $\mathrm{Zn}$ and $\mathrm{Ca}$, bioavailability had to be taken into account. The RNI for $\mathrm{Zn}$ and Fe was that for diets with low bioavailability. As for $\mathrm{Ca}$, we multiplied the Ca content of Ca-rich foods by the estimated absorption efficacy (Ca is absorbed at $32 \cdot 1 \%$ from milk $v$. $17 \cdot 0 \%$ from white beans) ${ }^{(27,28)}$, which allowed for dairy products to be retained in the models.

The dietary guidelines for the prevention of chronic diseases ${ }^{(20)}$ were also included as nutritional criteria in the 
Table 1 Commonly consumed foods used for optimization of Benin diets

\begin{tabular}{|c|c|c|c|}
\hline Selected foods for linear programming & No. of people who consumed ( $n 541)$ & Average portion size (g) (edible part) & SD (g) \\
\hline Corn dough, non-fermented & 486 & 587.4 & $26 \cdot 1$ \\
\hline Unsweetened millet porridge (abokounkoko) & 26 & 343.7 & $76 \cdot 0$ \\
\hline White rice, cooked & 367 & $259 \cdot 1$ & $12 \cdot 2$ \\
\hline Fermented corn dough (akassa) & 326 & $345 \cdot 2$ & 19.7 \\
\hline Fresh corn kernels, boiled & 28 & $100 \cdot 0$ & $18 \cdot 9$ \\
\hline Corn on cob, boiled & 26 & $150 \cdot 0$ & $21 \cdot 6$ \\
\hline White wheat bread & 255 & $97 \cdot 7$ & $5 \cdot 7$ \\
\hline Sweetened wheat doughnut (yovodoko) & 62 & $108 \cdot 1$ & $50 \cdot 1$ \\
\hline Boiled macaroni & 99 & 195.9 & $26 \cdot 3$ \\
\hline Boiled cassava & 23 & $123 \cdot 2$ & $23 \cdot 6$ \\
\hline Fermented cassava (gari) & 286 & $104 \cdot 3$ & 7.8 \\
\hline Unsweetened tapioca & 23 & 229.0 & $52 \cdot 4$ \\
\hline Cassava couscous (atiéké) & 15 & $144 \cdot 7$ & $40 \cdot 9$ \\
\hline Cooked yam & 76 & $115 \cdot 8$ & $19 \cdot 0$ \\
\hline Yam dough (teloubo) & 31 & $364 \cdot 7$ & $49 \cdot 7$ \\
\hline Cooked sweet potato & 16 & 83.4 & $56 \cdot 1$ \\
\hline Fresh plantain, cooked & 22 & $173 \cdot 3$ & $27 \cdot 2$ \\
\hline White beans, cooked (white niébé) & 165 & 244.0 & $26 \cdot 3$ \\
\hline Red beans, cooked (red niébé) & 83 & $330 \cdot 8$ & $42 \cdot 0$ \\
\hline Bean cake $(a b l a)$ & 40 & 73.8 & $12 \cdot 4$ \\
\hline Soya porridge, unsweetened & 8 & 347.5 & $125 \cdot 0$ \\
\hline Voandzou, boiled & 18 & 145.5 & $47 \cdot 1$ \\
\hline Squash seeds (goussi) & 32 & $42 \cdot 2$ & $13 \cdot 2$ \\
\hline Fresh coconut & 43 & $119 \cdot 8$ & $37 \cdot 0$ \\
\hline Grilled peanuts & 169 & 44.4 & $3 \cdot 2$ \\
\hline Palm nut flesh, puréed & 60 & 148.5 & 7.4 \\
\hline Rabbit & 13 & $45 \cdot 8$ & $30 \cdot 9$ \\
\hline Cooked beef, medium fat content & 68 & 51.7 & $17 \cdot 3$ \\
\hline Cooked pork & 14 & $72 \cdot 3$ & $35 \cdot 0$ \\
\hline Cooked lean lamb & 71 & $59 \cdot 0$ & 8.9 \\
\hline Cooked chicken & 58 & $87 \cdot 1$ & $16 \cdot 8$ \\
\hline Cooked tilapia fish & 469 & $76 \cdot 6$ & 6.5 \\
\hline Cooked freshwater crab & 126 & $97 \cdot 8$ & 11.3 \\
\hline Sardines & 21 & $70 \cdot 0$ & 9.5 \\
\hline Fresh cooked mackerel (sylvie) & 271 & 73.9 & $2 \cdot 9$ \\
\hline Boiled chicken eggs & 75 & $44 \cdot 0$ & 4.6 \\
\hline Evaporated unsweetened milk (peak) & 16 & $59 \cdot 0$ & $25 \cdot 5$ \\
\hline Local cheese & 48 & $52 \cdot 4$ & $12 \cdot 1$ \\
\hline Traditional yoghurt & 9 & $103 \cdot 2$ & $101 \cdot 8$ \\
\hline Fresh papaya & 21 & $390 \cdot 4$ & $152 \cdot 0$ \\
\hline Fresh sweet banana & 39 & $167 \cdot 7$ & $45 \cdot 3$ \\
\hline Fresh orange & 88 & 139.5 & $18 \cdot 9$ \\
\hline Fresh mango & 12 & $150 \cdot 1$ & $53 \cdot 4$ \\
\hline Fresh pineapple & 37 & $140 \cdot 7$ & $40 \cdot 9$ \\
\hline Fresh orange juice, $100 \%$ & 57 & 79.7 & 18.5 \\
\hline Tomatoes & 147 & $72 \cdot 6$ & $42 \cdot 6$ \\
\hline Tomato sauce & 464 & 151.4 & $10 \cdot 5$ \\
\hline Cooked carrots & 19 & 55.9 & 30.7 \\
\hline Amaranth leaves (crin-crin) & 174 & 137.5 & $20 \cdot 3$ \\
\hline Vegetable sauce & 271 & 238.0 & $20 \cdot 6$ \\
\hline Red palm oil & 134 & $18 \cdot 0$ & 1.6 \\
\hline Peanut oil & 224 & $12 \cdot 8$ & 0.9 \\
\hline
\end{tabular}

LP models for adults (Table 2). Recommendations for linoleic and linolenic acids were not integrated into the models because of the lack of data in the available food composition tables. For children, protein requirements were according to the WHO report ${ }^{(24)}$; for fat and carbohydrates, we used the Institute of Medicine's recommended intake ${ }^{(25)}$.

\section{Local dietary intake data}

The second set of constraints was there to make sure that recommended foods and amounts would be acceptable and relevant. We used in LP models quantitative dietary data from cross-sectional studies on the nutrition transition and CVD risk factors in apparently healthy adults aged $25-60$ years ( $n$ 541) and living in Cotonou, Benin's economic capital, the smaller city of Ouidah and adjacent rural areas ${ }^{(29-32)}$. A multistage random sampling on the area, living compound and sex was performed to select participants. The data were collected in 2005 and 2006. Intakes of energy and nutrients were assessed with two to three non-consecutive $24 \mathrm{~h}$ food consumption recalls. The portion sizes of consumed foods were assessed using local measurements: bowls, spoons, and in the case of street foods, the corresponding expense so that amounts 
Table 2 Recommended nutritional intake to prevent chronic diseases ${ }^{(20)}$

\begin{tabular}{ll}
\hline Dietary factor & Goal \\
\hline Total fat $^{*}$ & $15-30 \%$ \\
SFA $^{*}$ & $<10 \%$ \\
PUFA $^{*}$ & $6-10 \%$ \\
Proteins & $10-15 \%$ \\
Total carbohydrates & $55-75 \%$ \\
Free sugars† & $<10 \%$ \\
Cholesterol & $<300 \mathrm{mg} / \mathrm{d}$ \\
Fruits and vegetables & $>400 \mathrm{~g} / \mathrm{d}(250 \mathrm{~g}$ of vegetables and $150 \mathrm{~g}$ of fruits $)$ \\
Total dietary fibre & $>25 \mathrm{~g} / \mathrm{d}$ \\
\hline
\end{tabular}

*Percentage of total energy needs.

†'Free sugars' refers to monosaccharides and disaccharides added to foods and beverages by the manufacturer, cook or consumer, and naturally occurring sugars in honey, syrups.

could later be ascertained. This way meals and snacks consumed outside the home were included. Dietary quality data based on a micronutrient adequacy score and a prevention score were also available ${ }^{(30,31)}$. The micronutrient adequacy score is based on the compliance or not with fourteen micronutrients and the prevention score is based on the adherence or not to eight recommendations by the WHO for chronic disease prevention.

Based on the survey data, the most commonly eaten foods were identified, as well as average portion size (grams) for participants who had consumed the food item. Amounts of food consumed by those participants in the upper tertile of overall dietary quality (total of both quality scores) were used for optimization by LP. Data were analysed using the statistical software package SPSS Statistics version 17.

Two consumption constraints were introduced in LP models. First, a maximal amount per food category was set using dietary quality data based on a micronutrient adequacy score and a prevention score of those participants in the upper tertile of overall dietary quality. Two standard deviations above their mean intake per $4184 \mathrm{~kJ}$ (1000 kcal), multiplied by the energy needs of the corresponding age and sex group, was used as a maximal amount per food category. One exception was the dairy product category since consumption was very low. In order to meet $\mathrm{Ca}$ requirements, the maximum amount was set at $100 \mathrm{~g}$ of milk (or other dairy products) daily for models with the Ca RNI of less than $700 \mathrm{mg} / \mathrm{d}$ (providing 30-35\% of the RNI for Ca) and $200 \mathrm{~g}$ of milk (or other dairy products) daily for models with Ca requirements of 1000 to $1300 \mathrm{mg} / \mathrm{d}$ (dairy would then provide $20-25 \%$ of the RNI for $\mathrm{Ca}$ ).

The second constraint was a maximum amount per individual food item, which was set at the average portion size for all participants consuming the food (Table 1). Limiting the serving size to the average portion forced the mathematical model to select a variety of foods instead of optimizing large servings for a small selection of foods. For animal-protein foods, the upper limit was set above the typical average portion size in order to provide a minimum of $15 \mathrm{~g}$ of protein per portion and for adequate haem-Fe and $\mathrm{Zn}$ intakes. The maximal amount for the dairy product food group was also increased to ensure proper Ca intake. The consumption features of the fifty-two selected foods for LP are presented according to food group in Table 1, along with the number of people who reported having consumed the food item and the average portion size according to the $24 \mathrm{~h}$ food recalls ${ }^{(29,30)}$.

\section{Determination of recommended number and size of servings per food group}

In each food group, the size of one serving was defined on the basis of the usual amount consumed at any one time by the population and on macronutrient content criteria, as seen in Table 3, except that for dairy products, Ca content was used to define one serving. The LP results in grams for a given food group were then translated into a number of portions. Subsequently, the portion of a given food was associated with a local domestic measure. For example, $400 \mathrm{~g}$ of non-fermented corn dough $=120 \mathrm{~g}$ of carbohydrates $=2$ portions $=2$ local bowls $(250 \mathrm{ml} \mathrm{each})$. The serving size of cereals and tubers was set as much as possible at the amount actually consumed so that the recommended number of servings would be easier to understand and integrate into daily diet.

Tables 4 and 5 describe the adjustments made to all LP models. In some models, no plausible solution was found and therefore the intake criterion was lowered to $70 \%$ of the RNI for limiting nutrients (Ca, Fe, Zn, folic acid) ${ }^{(23)}$. As RNI are set at 2 SD above mean requirements, reducing the recommended intake constraint to $70 \%$ of the RNI amounts to using the average requirement, meaning that half the population would still meet their requirements for the given limiting micronutrient ${ }^{(23)}$. The RNI for vitamin $\mathrm{B}_{12}$ was not included in the models without animal foods. WHO recommendations for the prevention of chronic diseases were not used for children, because these recommendations were built mainly for adults.

Forty local key-players in nutrition were invited to take part in the individual and group consultations. In total, thirty of them were met for the consultations. These people were invited early in the process to take part in the food guide development. They were members of various local organizations involved in food and health: government officers, 
Table 3 Nutrient content criteria for one serving per food group

\begin{tabular}{|c|c|c|c|}
\hline & Carbohydrates & Proteins & Other(s) \\
\hline Cereals and tubers & 50 to $60 \mathrm{~g}$ & & \\
\hline Vegetables and vegetable sauces & $\begin{array}{l}1 \text { medium-size vegetable or } 8 \mathrm{~g} \text { of } \\
\text { carbohydrates for sauces }\end{array}$ & & \\
\hline Animal protein sources & & $15 \mathrm{~g}$ & \\
\hline Vegetable protein sources & & $15 \mathrm{~g}$ & \\
\hline Fruits & $15 \mathrm{~g}$ & & \\
\hline Dairy products & & & $250 \mathrm{mg}$ of $\mathrm{Ca}$ \\
\hline
\end{tabular}

Table 4 Constraint modifications in linear programming models for adults

\begin{tabular}{|c|c|c|c|c|c|c|c|c|}
\hline \multirow{3}{*}{$\begin{array}{l}\text { Mathematical models } \\
\text { Model }^{\star}\end{array}$} & \multicolumn{8}{|c|}{ Models for 19 years of age and above } \\
\hline & \multicolumn{2}{|c|}{ Women } & \multicolumn{2}{|c|}{ Men } & \multicolumn{2}{|c|}{ Pregnant women } & \multicolumn{2}{|c|}{ Lactating women } \\
\hline & 1 & 2 & 1 & 2 & 1 & 2 & 1 & 2 \\
\hline \multicolumn{9}{|l|}{ Nutritional constraints } \\
\hline \multicolumn{9}{|l|}{ RNI criteria } \\
\hline $\mathrm{Ca}$ & & & & & $70 \%$ & $70 \%$ & & \\
\hline $\mathrm{Zn}$ & & & & & & $70 \%$ & $70 \%$ & $70 \%$ \\
\hline Vitamin $\mathrm{B}_{12}$ & NA & & NA & & NA & & NA & \\
\hline $\mathrm{Fe}$ & & $70 \%$ & & & $70 \%$ & $70 \%$ & & $70 \%$ \\
\hline Folate & & $70 \%$ & & & $70 \%$ & $70 \%$ & & $70 \%$ \\
\hline \multicolumn{9}{|l|}{ Dietary habits constraints } \\
\hline \multicolumn{9}{|l|}{ Maximum amount per food group } \\
\hline $\begin{array}{l}\text { Dairy products } \\
\text { Upper limit per food }\end{array}$ & $200 \mathrm{~g}$ & $200 \mathrm{~g}$ & $200 \mathrm{~g}$ & $200 \mathrm{~g}$ & $200 \mathrm{~g}$ & $200 \mathrm{~g}$ & $200 \mathrm{~g}$ & 2000 \\
\hline Meat portion size increased & & Yes & & Yes & & Yes & & Yes \\
\hline
\end{tabular}

RNI, Recommended Nutrient Intake; NA, not applicable.

*Model 1 includes all fifty-two most commonly eaten foods except for animal-protein foods; Model 2 includes all most commonly eaten foods except for vegetable-protein foods.

academics, non-governmental organizations, private institutions and representatives of international organizations. The interactions were individual and group consultations to reach consensus at every step of the process.

\section{Results}

\section{Number and size of servings according to age-sex groups}

The recommended numbers of servings per food group and per day as determined with the help of LP are given for each age-sex group in Table 6. For dairy products, the recommended number of servings is slightly higher than typical eating habits in order to meet $\mathrm{Ca}$ intake requirements. The number of recommended servings for protein foods had to be adjusted for cultural reasons. According to calculations, women aged 19 years and over should consume three portions of animal- or vegetable-protein foods daily and men should consume two to three servings of this food group. The difference can be explained by the higher Fe requirements for women than for men. However, according to local experts, recommending a higher number of servings for women than men would not be culturally acceptable. Consequently, the number of servings was set at 2-3 for women as for men, with an indication for women of childbearing age to take $\mathrm{Fe}$ and folic acid supplements according to local health and nutrition policy.

\section{Individual food portion sizes}

Portion sizes in grams and domestic measures were determined according to the nutritional composition of specific foods based on the reference food composition tables ${ }^{\text {(33-35) }}$ and taking into account the nutrition content criteria for one portion of each food group as presented in Table 3. As much as possible, the amount usually consumed on one occasion was used as serving and portion, in order to avoid the frequent confusion among consumers when servings and portions are different ${ }^{(36)}$. Examples of illustrative foods and serving sizes are given in Table 7 . The domestic or simple measures chosen with local partners to illustrate portion size were a standard bowl used to serve the corn dough $(250 \mathrm{ml})$, a tablespoon $(15 \mathrm{ml})$ and a 'bamboo' glass $(215 \mathrm{ml})$. Additionally, it was agreed to use as reference the hand palm or thumb phalanx ${ }^{(37)}$.

\section{Discussion}

The current study describes how LP was used to develop locally relevant and nutritionally adequate FBDG in the 
Table 5 Constraint modifications in linear programming models for children and adolescents

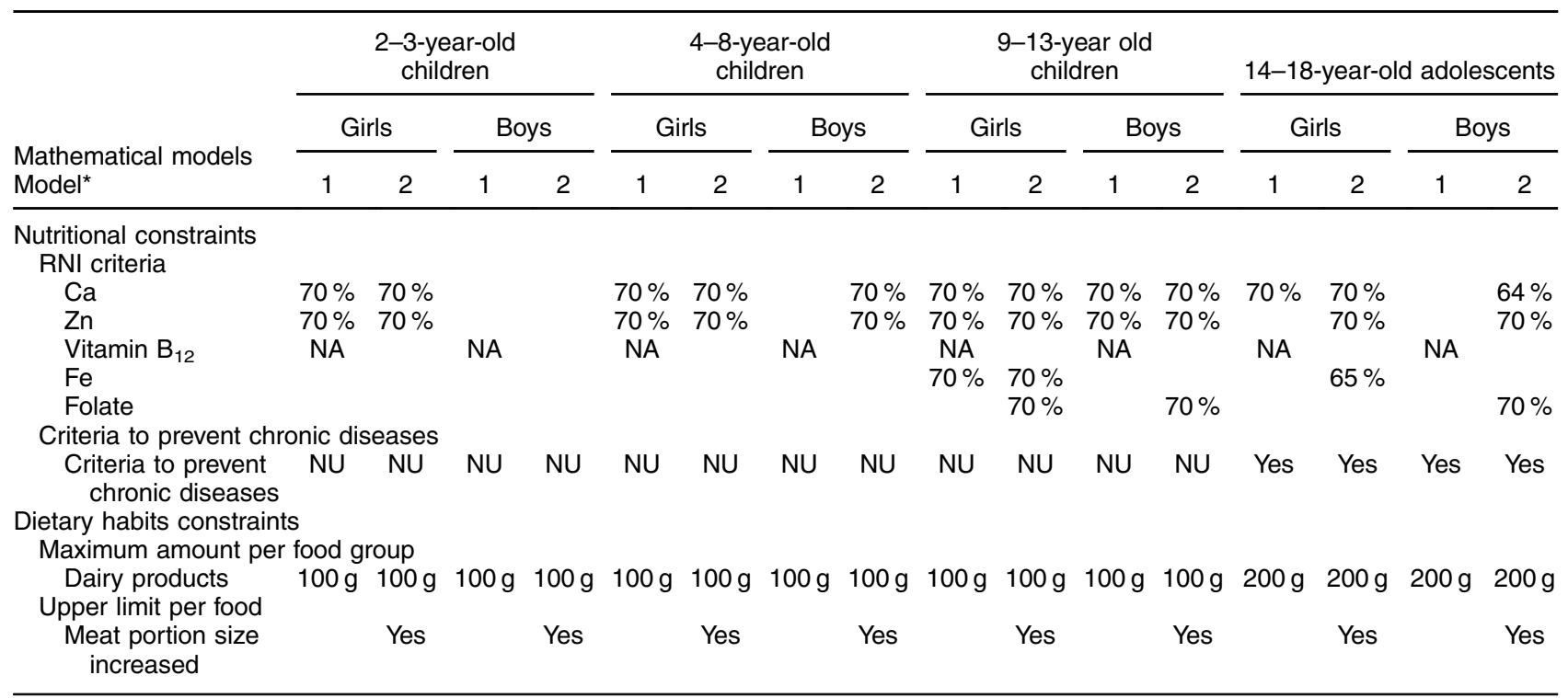

RNI, Recommended Nutrient Intake; NA, not applicable; NU, not used.

*Model 1 includes all fifty-two most commonly eaten foods except for animal-protein foods; Model 2 includes all most commonly eaten foods except for vegetable-protein foods.

Table 6 Number of recommended daily servings per food group according to age and sex

\begin{tabular}{|c|c|c|c|c|c|c|c|c|c|}
\hline \multirow[b]{2}{*}{ Food group } & \multirow[b]{2}{*}{$\begin{array}{l}\text { 2-3-year- } \\
\text { old children }\end{array}$} & \multirow[b]{2}{*}{$\begin{array}{l}\text { 4-8-year- } \\
\text { old children }\end{array}$} & \multirow[b]{2}{*}{$\begin{array}{l}\text { 9-13-year } \\
\text { old children }\end{array}$} & \multicolumn{2}{|c|}{$\begin{array}{l}\text { 14-18-year-old } \\
\text { adolescents }\end{array}$} & \multicolumn{4}{|c|}{19 years of age and above } \\
\hline & & & & Girls* & Boys & Women* & Men & $\begin{array}{l}\text { Lactating } \\
\text { women* }^{*}\end{array}$ & $\begin{array}{l}\text { Pregnant } \\
\text { women* }\end{array}$ \\
\hline Cereals and tubers & $2-3$ & $2-4$ & $3-4$ & $4-6$ & $5-7$ & $3-5$ & $4-6$ & $5-6$ & $4-6$ \\
\hline $\begin{array}{l}\text { Vegetables and } \\
\text { vegetable sauces }\end{array}$ & $2-3$ & $3-5$ & $4-5$ & $4-6$ & $5-6$ & $4-6$ & $4-6$ & $4-6$ & $4-6$ \\
\hline $\begin{array}{l}\text { Meat, fish, legumes } \\
\text { and other sources } \\
\text { of protein }\end{array}$ & 1 & $1-2$ & $1-2$ & $2-3$ & $2-3$ & $2-3$ & $2-3$ & 3 & $2-3$ \\
\hline Fruits & 1 & $1-3$ & $2-3$ & $2-3$ & $2-3$ & $2-3$ & $2-3$ & $2-3$ & $2-3$ \\
\hline Dairy products $†$ & 1 & 1 & 1 & $1-2$ & 2 & $1-2$ & $1-2$ & $1-2$ & $1-2$ \\
\hline
\end{tabular}

*Women of childbearing age can benefit from an Fe-folic acid supplement as prescribed by their health-care provider, since their needs are difficult to satisfy with nutrition only.

†lf dairy products are not available or accessible, they can be replaced with small dried fish or crabs (eaten whole), for example.

form of a quantitative food guide, in this instance in the Republic of Benin, along with a participatory approach with local partners in food and nutrition. National FBDG are strongly recommended as educational tools to be used with the population ${ }^{(7)}$, but in sub-Saharan Africa, only South Africa and Namibia went through the complex process of developing such guidelines ${ }^{(38,39)}$. In Benin, the recent epidemiological studies on cardiometabolic risk associated with diet and lifestyle changes typical of the nutrition transition and the availability of quantitative dietary data collected in these studies gave impetus to the development of a food guide for the general population as a preventive educational tool, with the help of LP.

LP has been used for various nutrition purposes and in many contexts: in the USA to generate nutritive diets at a low cost; in Israel to plan menus with a good ratio of price to quality; and in Malawi to develop guidelines for complementary feeding of infants and toddlers ${ }^{(40)}$. Ours is probably the first study to use LP for the purpose of developing a national food guide.

It was not possible to optimize local diets with LP for some micronutrients unless the nutritional criteria were lowered to $70 \%$ of the recommended intakes, which nevertheless would still be sufficient to meet the requirements of half the population. The limiting micronutrients in our study were $\mathrm{Ca}$, $\mathrm{Fe}, \mathrm{Zn}$, vitamin $\mathrm{B}_{12}$ (if no animal sources of protein are consumed) and folic acid, in accordance with the most widespread dietary deficiencies reported worldwide ${ }^{(41)}$. In order to prevent deficiencies in these limiting nutrients, higher amounts of foods or food groups also had to be 'forced' into some LP models, in addition to lowering the recommended intakes. This was the case for dairy products 
Table 7 Illustrative foods and serving sizes

\begin{tabular}{|c|c|c|}
\hline Food item & Weight $(\mathrm{g})$ & Serving size measurements \\
\hline \multicolumn{3}{|l|}{ Cereals } \\
\hline Corn dough, non-fermented & 185 & 1 bowl \\
\hline Cooked white rice & 220 & 1 bowl \\
\hline Fermented corn dough (akassa) & 185 & 1 bowl \\
\hline Boiled macaroni & 160 & 3/4 bowl \\
\hline White wheat bread & 87.5 & $1 / 2$ bread \\
\hline Unsweetened millet porridge (abokounkoko) & 450 & 2 bowls \\
\hline \multicolumn{3}{|l|}{ Tubers and roots } \\
\hline Boiled cassava & $185-200$ & 1 bowl \\
\hline Cooked yam & $185-200$ & 1 bowl \\
\hline Cooked sweet potato & $185-200$ & 1 bowl \\
\hline Yam dough (teloubo) & 175 & 1 bowl \\
\hline Fermented cassava (garı) & 60 & $1 / 4$ bowl \\
\hline \multicolumn{3}{|l|}{ Vegetables and vegetable sauces } \\
\hline Fresh tomato & 100 & 2 medium \\
\hline Tomato sauce & 100 & 1 bowl \\
\hline Carrot & 60 & 1 medium \\
\hline Leafy vegetables & 60 & 2 bowls \\
\hline Leafy vegetable sauce & 80 & $1 / 2$ bowl \\
\hline \multicolumn{3}{|l|}{ Beans, nuts and seeds } \\
\hline Cooked white beans (white niébé) & 140 & $1 / 2$ bowl \\
\hline Cooked red beans (red niébé) & 140 & $1 / 2$ bowl \\
\hline Soya porridge, unsweetened & 100 & $1 / 2$ bowl \\
\hline Vouandzou & 50 & $1 / 5$ bowl \\
\hline Grilled peanuts & 50 & $1 / 3$ bowl \\
\hline \multicolumn{3}{|l|}{ Fruits } \\
\hline Fresh papaya & 150 & 1 bowl \\
\hline Fresh banana & 75 & 1 medium \\
\hline Fresh orange & 100 & 1 medium \\
\hline Fresh mango & 100 & 1 small or $1 / 2$ large \\
\hline Fresh pineapple & 150 & 1 bowl \\
\hline Pure orange juice & $150 \mathrm{ml}$ & $3 / 4$ glass \\
\hline \multicolumn{3}{|l|}{ Dairy products } \\
\hline Evaporated unsweetened milk (peak) & 85 & $1 / 2$ milk box \\
\hline Local cheese & 50 & The length of two thumbs \\
\hline Traditional yoghurt & 125 & 1 small container \\
\hline
\end{tabular}

as sources of $\mathrm{Ca}$ and for animal-protein foods for $\mathrm{Fe}, \mathrm{Zn}$ and vitamin $\mathrm{B}_{12}$. Additional recommendations were also introduced in the food guide. For $\mathrm{Ca}$, for instance, although dairy products are little consumed at this time and primarily by urban dwellers, the food group was maintained and 1-2 servings of dairy products daily are recommended. If dairy products are not accessible, we advised that Ca-rich foods like dried or smoked small fish, small crabs and fresh or dried shrimps eaten whole be consumed. It is of note that adolescents from Porto-Novo, the capital city of Benin, had reportedly adequate $\mathrm{Ca}$ intake thanks to these $\mathrm{Ca}$-rich foods ${ }^{(42)}$. There were no data on the serving sizes of the different foods consumed by adolescents in that study. Fe was also a limiting nutrient especially in adolescent girls' and women's LP models, which is not surprising as the Fe requirements of women of reproductive age can hardly be met with food alone, particularly when diets provide for low bioavailability of Fe. This is why Fe (and folate) supplements are generally recommended for women of childbearing age $e^{(43,44)}$. According to Benin health and nutrition policy, Fe-folate supplements during pregnancy are sold to women at a subsidized price.

This food guide targets urban and semi-urban populations in particular, as it implies that recommended foods are available, accessible and desirable. It is felt that such an educational tool may be less relevant at this stage in rural areas, where food intake is primarily determined by local availability (and accessibility) of foodstuffs. Besides, food intake data used to optimize local diets were mostly collected in urban and semi-urban areas (370 participants out of a total of 541). In cities, food supplies are usually more varied, processed imported foods are available and there is room for choice on the part of consumers, provided they have economic access to, and desire for, a diversified diet. A cost constraint could have been inserted in the LP models in order to optimize local diets at lower cost. Previous studies have demonstrated the adverse effect of a cost constraint in LP on nutrient density of diets and food selection ${ }^{(45)}$. However, the number of constraints that could be introduced in LP at the time of the study was limited. Nevertheless, since foods retained for the LP models were the ones most frequently consumed, it was assumed that they were accessible to a majority. Despite this, as experienced elsewhere, the challenge of reaching the low-income population is a barrier to successful implementation of $\mathrm{FBDG}^{(16)}$.

The numbers of food servings for age-sex groups are based on average energy requirements for moderately 
active subjects; these have to be adjusted to an individual's energy requirements based on physical activity, particularly as regards staple cereals and tubers as main providers of energy ${ }^{(46)}$. Similarly, the present food guide would have to be adapted to different ecological and cultural contexts within the country, as it is based on diets in the southern and coastal part of Benin. Dietary patterns may markedly differ in the hinterland and in drier northern areas.

Another limitation of the study is the fact that the food guide was based on data quantitatively collected only among adults; no data from children or adolescents were suitable for use in LP models. One study provides data on energy, Ca and P consumption in adolescents; however, it does not provide information on portion sizes ${ }^{(42)}$. It was assumed that children have similar eating habits to their parents. The gap related to the non-availability of food consumption data for children and adolescents can partly be filled when the food guide is revised in a few years. Health and nutrition professionals using the food guide with these age groups will then be able to identify the discrepancies between the recommendations and the actual eating habits, particularly in terms of portion sizes. Additionally, more food consumption data pertaining to children and adolescents may become available. Ideally, the food guide should be revised every four years, but much will depend on technical and financial resources.

Food composition data are incomplete for some traditional food items and for cooked foods. Therefore, some nutrient intakes might have been over- or underestimated.

The data were collected in different settings - urban, semi-urban, rural - albeit only in the southern part of the country. We selected the most commonly eaten foods in our LP models because we estimated that if they are eaten often they are likely physically and economically accessible. Like any food guide, alternative choices are provided within food groups as not all foods are available and accessible in all areas and throughout the year. Animal foods are not accessible to everyone; this is why we developed two models: one with animal foods and one without. The results from the two models were then combined to give one recommendation for the 'meat, fish, beans and other protein foods' group so that most people are able to select in this group the foods that they have access to.

The local domestic measures used to translate servings into easily understood amounts may foster better compliance to the recommended portion numbers and sizes because they are commonly used and familiar to the general population, as underlined in developing the Taiwan food guide $^{(47)}$.

The food guide has now been officially adopted in Benin. Its development involved the participation of a wide array of local key-players in food and nutrition. The ten recommendations illustrated in the food guide, as well as the choice of the food groups for this guide, were developed and tested with local groups of adults (self-help groups for the prevention of chronic diseases; parentteacher associations). However, the food guide has not been tested in its entirety with the population as yet. This will be done during the course of its implementation. Another critical step will be to foster its appropriate use by health and nutrition workers with groups and individuals, primarily through appropriate training. The early involvement of Benin stakeholders in the food guide development process is likely to facilitate its acceptance and its integration with other health promotion policies and programmes. A user-friendly explanatory text will have to be developed to provide personnel guidance on the use of the food guide. However, FBDG are only one educational tool. In order to be effective, dietary interventions have to be comprehensive, population-based, integrated, multidisciplinary and multisectorial ${ }^{(48)}$. Besides a healthy diet, other lifestyle components have to be addressed, including physical activity, and the Benin food guide promotes an active lifestyle though pictures. Implementation of the new Benin food guide will have to be integrated not only into public health, but also agriculture, food and education policy. Additionally, a comprehensive communication strategy will be needed. It will also be important once the Benin food guide is established to plan for its monitoring and evaluation. FBDG would need to be better evaluated than what is currently done in order to be regularly revised for enhanced impact on the population's diets and nutritional status ${ }^{(49)}$. FBDG are an evolving tool needing periodic updating and improvements.

\section{Conclusion}

To our knowledge, the present study is the first to have put LP to use for the development of a national food guide, which confers greater cultural and environmental relevance to recommended foods and servings. Several challenges still lie ahead, including the formulation of a strategy on how the food guide should be used to improve dietary patterns of the population. A food guide is a constant work in progress and according to the $\mathrm{FAO}^{(7)}$, it should be revised every four years. Before revisions, this first version of the food guide will have to be pre-tested and its relevance assessed in other cities of the country. In the near future, the use of this tool by health-care providers and its impact on behavioural change in the local population will have to be evaluated, thereby filling a research gap.

\section{Acknowledgements}

Financial support: The field work for this specific study in Benin was supported by Global Health Axis of 'Réseau de recherche en santé des populations du Québec' (Research Network of Population's Health of Quebec). The Benin project on the double burden of malnutrition in which this study is nested is funded by the Canadian International 
Development Agency (CIDA; grant number S064359). Global Health Axis and CIDA had no role in the design, analysis and writing of this article. Conflict of interest: None. Authorship: S.L. developed the LP tool, conducted the field work, analysed the data and wrote the manuscript. H.D. designed the study, supervised data analysis and corrected the manuscript. V.A. coordinated and supervised the field work, and reviewed the manuscript. Ethics of buman subject participation: Ethical approval was not required.

\section{References}

1. World Health Organization (2011) Noncommunicable Diseases Country Profile. WHO Global Report. Geneva: WHO.

2. Abegunde DO, Mathers CD, Adam T et al. (2007) The burden and costs of chronic diseases in low-income and middle-income countries. Lancet 370, 1929-1938.

3. Lim SS, Vos T, Flaxman AD et al. (2012) A comparative risk assessment of burden of disease and injury attributable to 67 risk factors and risk factor clusters in 21 regions, 1990-2010: a systematic analysis for the Global Burden of Disease Study 2010. Lancet 380, 2224-2260.

4. Seidell JC (2005) Epidemiology of obesity. Semin Vasc Med 5, 3-14

5. Delisle HF (2008) Poverty: the double burden of malnutrition in mothers and the intergenerational impact. Ann NY Acad Sci 1136, 172-184.

6. Delisle H (2012) Empowering our profession in Africa. World Public Health Nutr Assoc 3, 269-284.

7. World Health Organization/Food and Agriculture Organization of the United Nations (1998) Preparation and Use of Food Based Dietary Guidelines. Report of a Joint WHO/ FAO Consultation. WHO Technical Report Series no. 880. Geneva: WHO.

8. Food and Agriculture Organization of the United Nations (2009) Food Guidelines by Country. http://www.fao.org/ $\mathrm{ag} /$ humannutrition/nutritioneducation/fbdg/en/ (accessed August 2013).

9. World Health Organization (2003) Food Based Dietary Guidelines in the WHO European Region. Copenhagen: WHO Regional Office for Europe.

10. Vorster HH, Love P \& Browne C (2001) Development of food-based dietary guidelines for South-Africa - the process. $S$ Afr J Clin Nutr 14, Suppl, S3-S6.

11. Koeing JS (2007) Visualization of food-based dietary guidelines - examples. Ann Nutr Metab 51, 36-42.

12. Painter J, Rah JH \& Lee YK (2002) Comparison of international food guide pictorial representations. J Am Diet Assoc 102, 483-489.

13. Brown KA, Timotijevic L, Barnett J et al. (2011) A review of consumer awareness, understanding and use of food-based dietary guidelines. BrJ Nutr 106, 15-26.

14. Takaizumi K, Harada K, Shibata A et al. (2011) Influence of awareness of the Japanese Food Guide Spinning Top on eating behavior and obesity. Asia Pacific J Clin Nutr 20, 95-101.

15. McCullough ML, Feskanich D, Stampfer MJ et al. (2000) Adherence to the Dietary Guidelines for Americans and risk of major chronic disease in women. Am J Clin Nutr 72, 1214-1222.

16. Keller I \& Lang T (2008) Food-based dietary guidelines and implementation: lessons from four countries - Chile, Germany, New Zealand and South Africa. Public Health Nutr 11, 867-874.

17. Gibney M \& Vorster H (2001) South-African food-based dietary guidelines. S Afr J Clin Nutr 14, Suppl, S1-S80.
18. Houinato D, Segnon Agueh J, Dirolo F et al. (2008) Rapport final de l'enquête STEPS au Bénin. Report of a Joint Collaboration, WHO and Benin Health Ministry. http://www. who.int/chp/steps/2008_STEPS_Report_Benin.pdf (accessed August 2013).

19. World Health Organization (2011) United Nations high-level meeting on noncommunicable disease prevention and control. http://www.who.int/nmh/events/un_ncd_summit2011/ en/ (accessed August 2013).

20. World Health Organization (2004) Global Strategy on Diet, Physical Activity and Health. Geneva: WHO.

21. Ferguson EL, Darmon N, Briend A et al. (2004) Food-based dietary guidelines can be developed and tested using linear programming analysis. J Nutr 134, 951-957.

22. National Institutes of Health (2007) Dietary Supplement Fact Sheet: Iron. http://ods.od.nih.gov/factsheets/Iron-HealthProfessional/ (accessed August 2013).

23. World Health Organization/Food and Agriculture Organization of the United Nations (2001) Human Vitamin and Mineral Requirements. Report of a Joint FAO/WHO Expert Consultation, Bangkok, Thailand. Rome: FAO.

24. World Health Organization/Food and Agriculture Organization of the United Nations/United Nations University (2002) Protein and Amino Acid Requirements in Human Nutrition. Report of a Joint FAO/WHO/UNU Expert Consultation. WHO Technical Report Series no. 935. Geneva: WHO/FAO/UNU.

25. Food and Nutrition Board, Institute of Medicine, National Academies (2011) Dietary Reference Intakes (DRIs): Estimated Average Requirements. http://iom.edu/Activities/Nutrition/ SummaryDRIs/ /media/Files/Activity\%20Files/Nutrition/DRIs/ New\%20Material/5DRI\%20Values\%20SummaryTables\%2014. pdf (accessed August 2013).

26. World Health Organization/Food and Agriculture Organization of the United Nations/United Nations University (2001) Human Energy Requirements. Report of a Joint WHO/FAO/UNO Expert Consultation, Rome, 17-24 October 2001. FAO Food and Nutrition Technical Report Series no. 1. Rome: FAO.

27. Weaver C \& Heaney R (editors) (2006) Food sources, supplements and bioavailability. In Calcium in Human Health, pp. 129-144. Towata, NJ: Humana Press.

28. Weaver CM \& Plawecki KL (1994) Dietary calcium: adequacy of a vegetarian diet. Am J Clin Nutr 59, 5 Suppl., 1238S-1241S.

29. Ntandou G, Delisle H, Agueh V et al. (2009) Abdominal obesity explains the positive rural-urban gradient in the prevalence of the metabolic syndrome in Benin, West Africa. Nutr Res 29, 180-189.

30. Sodjinou R, Agueh V, Fayomi B et al. (2009) Dietary patterns of urban adults in Benin: relationship with overall diet quality and socio-demographic characteristics. Eur J Clin Nutr 63, 222-228.

31. Delisle H, Ntandou-Bouzitou G, Agueh V et al. (2012) Urbanisation, nutrition transition and cardiometabolic risk: the Benin study. Br J Nutr 107, 1534-1544.

32. Delisle H, Agueh V \& Fayomi B (2011) Partnership research on nutrition transition and chronic diseases in West Africa trends, outcomes and impacts. BMC Int Health Hum Rights 11, Suppl. 2, S10

33. Calloway DH, Murphy S, Bunch S et al. (1994) WorldFood 2 Dietary Assessment System. http://www.fao.org/infoods (accessed September 2011).

34. Nordeide M (1998) Table de composition d'aliments du Mali. Oslo: Institut de Nutrition.

35. Stadlmayr B, Charrondiere U, Enujiugha V et al. (2012) Table de composition des aliments d'Afrique de l'Ouest. Rome: FAO.

36. US Department of Agriculture (1999) Food portions and servings - How do they differ? Nutrition Insights - A Publication of the USDA Center for Nutrition Policy and 
Promotion no. 11; available at http://www.cnpp.usda.gov/ publications/nutritioninsights/insight11.pdf

37. Anderson A, Barton K, Craigie A et al. (2008) Exploration of Adult Food Portion Size Tools. Edinburgh: NHS Health Scotland.

38. Department of Health South Africa (2004) South African Guidelines for Healthy Eating for Adults and Children over the age of seven years. Pretoria: Department of Health South Africa.

39. Ministry of Health and Social Services (2000) Food E Nutrition Guidelines for Namibia. Food Choices for a Healthy Life. Windhoek, Namibia: National Food Security and Nutrition Council.

40. Darmon N \& Moy F (2008) Un outil à découvrir en nutrition humaine: la programmation linéaire. Cab Nutr Diet $\mathbf{4 3}$ 303-311.

41. Tulchinsky T (2010) Micronutrient deficiency conditions: global health issues. Public Health Rev 32, 243-255.

42. Dansou P, Akplogan B \& Avalla C-OW (2000) Apport énergétique et calcique dans l'alimentation des adolescents de la ville de Porto-Novo (République du Bénin). Médecine d'Afrique Noir 47, 357-361.

43. World Health Organization (2009) Weekly Iron-Folic Acid Supplementation (WIFS) in Women of Reproductive Age: Its
Role in Promoting Optimal Maternal and Child Health. Geneva: WHO.

44. Pena-Rosas JP \& Viteri FE (2009) Effects and safety of preventive oral iron or iron + folic acid supplementation for women during pregnancy. Cochrane Database Syst Rev issue 4, CD004736.

45. Darmon N, Ferguson E \& Briend A (2002) Linear and nonlinear programming to optimize the nutrient density of a population's diet: an example based on diets of preschool children in rural Malawi. Am J Clin Nutr 75, 245-253.

46. Yoshiike N, Hayashi F, Takemi Y et al. (2007) A new food guide in Japan: the Japanese food guide Spinning Top. Nutr Rev 65, 149-154.

47. Tzeng MS (2008) From dietary guidelines to daily food guide: the Taiwanese experience. Asia Pacific J Clin Nutr 17, Suppl. 1, 59-62.

48. Sandstrom B (2001) A framework for food-based dietary guidelines in the European Union. Public Health Nutr $\mathbf{4}$, 293-305.

49. European Food Information Council (2011) Food-Based Dietary Guidelines - are we on the right track? http://www. eufic.org/article/en/health-and-lifestyle/healthy-eating/artid/ Food-Based-Dietary-Guidelines-on-right-track/ (accessed August 2013). 